\title{
A missiological exploration of Australian missionary James Noble Mackenzie's ministry to lepers in South Korea
}

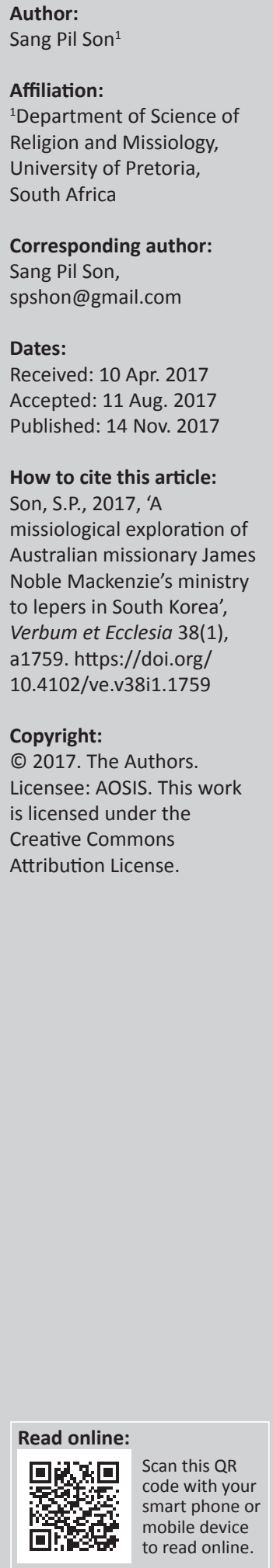

The history of Australian Presbyterian Mission in Korea (APM) is not comprehensive, nor the study of missiology that addresses the marginalised. This study of the ministry of APM missionary, J.N. Mackenzie, to lepers in Japanese-occupied Korea, adds significantly to both these areas. An understanding of the role and methods of Mackenzie's missionary activities among the marginalised in Korea can encourage today's Church to effectively restore the marginalised in society, moving from Church doctrine to practical reproduction of the example of Jesus recorded in Mark's gospel. Using original and published sources, the study examines the social conditions in which Mackenzie found Korean lepers, their historic treatment and government policies and the growth of his holistic mission, with its methods and fruits. Mackenzie's work is documented with recorded data included to demonstrate its Christ-like effectiveness both spiritually and physically. By tracing Mackenzie's work with lepers, it is clear that holistic mission can helpfully impact the situation of the most marginalised. Mackenzie's work expanded dramatically, churches were formed and it even created cured evangelists, making it a useful model for mission work among the marginalised. Mackenzie's work played a significant part in the Church and National history of Korea and presented a new path in the mission work of APM. It has the potential to influence modern mission in being 'as Christ' to the marginalised and thus to impact the society. This study has given a unique perspective on the history and theology of mission to the poor and traditionally powerless in society.

Intradisciplinary and/or interdisciplinary implications: Traditional views of history, theology and missiology have focussed on the ruling classes and urban societies. A perspective of the marginalised encourages a shift in these as it can be seen that the rural poor responded to holistic ministry and affected history and society. Such insights can give direction now.

\section{Introduction}

The purpose of this article is to make a missiological exploration of J.N. Mackenzie's ministry to leprosy sufferers in South Korea. Leprosy is almost completely subdued today, so there is no need to quarantine sufferers because $99.9 \%$ of the bacteria are sterilised by a single dose of antibiotic (Chae 2016). Therefore, leprosy is not a cause of rejection today and sufferers are regarded as neighbours who are disabled people. But in earlier times, this was not so and Mackenzie was a man who devoted 28 years to providing an effective mission to lepers. Today, the study of his work provides important lessons to pastors and missionaries and further to developing countries. To this end, this study will look at the actual condition of the lepers in South Korea at that time, the policy of government, the occasion where Mackenzie started missiological mission, the extension and fruit of mission and the therapeutic theology applied to leprosy.

James Noble Mackenzie (08 January 1865 - 15 November 1952) was born sixth son of the seven children of his father Kenneth Mackenzie and his mother Catherine Macrae in Isle of Ewe, Rossshire, Scotland. When he was 5 years old, his father died and his elder siblings were scattered to make their livelihoods, leaving only three children in the home (Mackenzie 1995:16). He and his two younger brothers moved with their mother to the small city of Plockton and then when he was 16 years old, he left home for the big city of Glasgow. After listening to D.L. Moody's preaching in Glasgow, he was 'determined to live a better life in future ...' (Mackenzie 1995:20-21). In a meeting of the 'Cambridge Seven', ${ }^{1}$ he became highly motivated to pursue his interest in foreign missions. He studied Humanities, Latin and Greek in the Glasgow University and then he entered the Trinity College of Free Church in 1891. At that time, he heard the preaching of John G. Paton 1.The Cambridge Seven were seven students from Cambridge University who volunteered as inland missionaries in China in 1885 
(1824-1905), who was one of the greatest missionaries of the 20th century, sent as a missionary by the Reformed Presbyterian Church of Scotland in 1858 to New Hebrides. Mackenzie met him and volunteered as a missionary to New Hebrides in February 1894 (Mackenzie's letter; Messenger 1909:67). At that time, he met Margaret Kelly (1870-1908, Maggie), a missionary candidate who was a nurse. They married and then, after receiving medical training for 13 weeks in the Glasgow hospital, they left Scotland for Melbourne, Australia. Mackenzie was ordained as a missionary of the Synod of North Melbourne, Presbyterian Church of Victoria (PCV). Then, the young couple entered Nogugu of the North-west area of the biggest island of the New Hebrides (today, Vanuatu), in the South Pacific. Unfortunately, their ministry for 15 years was stopped by the unexpected death of his lovely wife, Maggie (04 December 1908), and he received medical advice to leave the region permanently. He volunteered for mission to Korea (today, South Korea) and arrived in 1910. After 2 years, he remarried with Mary Jane Kelly (03 March 1880 - 11 January 1964) who had arrived as a missionary in Korea 5 years before him.

At the beginning, Mackenzie had the good fortune to live in the house of Rev. G. Engel who was 3 years older, and had arrived 10 years before in Busan, South Korea, ${ }^{2}$ and Engel provided both motivation and direction to itinerant evangelists in Busan and the surrounding area. Mackenzie wanted to travel to the villages in islands and coastal areas of the Masampo territory using a boat, as he had succeeded in Nogugu. However, the Japanese imperialist authorities did not allow the journey to take place as there were military bases in that area. In 1912, Mackenzie was assigned as an itinerate leader of five regions and he accepted that position (Busan Presbytery 2005:212). That work led to much time travelling (Mackenzie 1995:144) and he made a great deal of progress.

He also worked on ministries for women and children in the South Kyeongnam province and Busan. But above all, his prominent ministry was a ministry for the lepers. Let us look at his ministry of sublime dedication to lepers.

\section{Circumstances of leprosy and his ministry momentum}

Leprosy is one of the oldest diseases known to human race with a history possibly going back thousands of years (Suzuki Kawashima 2012:121). Today, almost 99.95\% of leprosy patients can be treated by antibiotics and they do not have to be isolated (Chae 2016). A hundred years ago, leprosy in Korea was known as 'punishment from heaven'.

At that time, a century ago, it was believed to be easily infectious, so when leprosy was found in the family or village, the leper was abandoned and his property was burned. Even dead bodies and household possessions were burned. It was also believed that lepers were being punished by gods and people protected the tombs by spreading bad rumours that the only cure was to eat the man's liver (Jeong 2007:355). Lepers usually collectively lived in a cave out of town or built huts under bridges and begged for their livelihood. But uncaring people threw stones at them to deter them from coming close. Even if they were cured, 'Once a leper, always a leper' was the belief and so they were not given work or a place in the village (Mackenzie Autobiography c.1949:40). Thus, lepers had been abandoned as the most marginalised people in the land, separated from the society and their families.

The number of lepers living in Korea at that time is not found in the government's data. But according to the estimates by the Society of Korean Leprologists, about 10000 people were suffering from leprosy after the Korean War, 1950-1953 (The Society of Korean Leprologists 2016), and about 40 years earlier Mackenzie had reported that there were about 10000 sufferers and that around 7000 of them lived in the South Kyeongsang Province (Mackenzie's letter; KMF 1921:82). Traditional religions with a history of millennia on the Korean Peninsula had not systematically looked after lepers or sought treatments for leprosy.

Moreover, the Japanese imperialist government, which was colonising Korea (1910-1945), did not pay any attention to them either. For example, according to an article by Mackenzie:
... the sanitary police on one occasion rooted out from all sorts of holes and corners fifty lepers, brought them to the beach below our house, and then came to ask what I could do for them ... Eight places were still empty. After explaining the position to the group ... The sanitary officer, though sympathetic, was emphatic that in his orders the others must not return to their old haunts and must not sleep anywhere within the Japanese part of the city ... (Mackenzie Autobiography c.1949:42-43)

In this way, the government abandoned them but did not take measures against them.

The Protestant mission to lepers in Korea was begun in Busan of the South Kyeongsang province by Dr C.H. Irvin who began to take care of lepers in 1894 and the work was handed over to Mackenzie in 1911. Dr R.W. Wilson of the Southern Presbyterian Church of USA (SPCUSA) also started working with lepers in 1911 in Gwangjoo of the South-eastern province, and also Dr A.G. Fletcher of the Northern Presbyterian Church of USA (NPCUSA) in 1914 in Taegu of the North Kyeongsang province (Jeong 2007:355-366). After this, the Japanese imperialists' government founded the Jahye-clinic Centre in 1916 in the isolated island of Sorok-do (SorokIsland) as a place to which lepers could be removed. ${ }^{3}$ They made a special law regarding lepers in 1931. It largely reflected missionaries' proposals. In addition, Mackenzie presented proposals to the medical conference in Osaka in November 1932 and they communicated with the government

3.Jahyeuiwon (Mercy Hospital) was a general hospital. There were 18 hospitals in the country and the 19th, Jahyeuiwon, was founded in Sorok-do (Sorok Island) as a special hospital for leprosy. 
for urgent action (Mackenzie's letter; KMF 1933:262). Following this, the Japanese government organised a Leper Relief Association in 1933 with a plan to build hospices to isolate 6000 lepers. In addition, in order to attempt to accommodate all of the leprosy sufferers in the country, they had already exploited workers by what amounted to using forced labour to house some lepers. Furthermore, the Japanese imperialists were preparing for Pacific warfare and employed forced labour by mobilising the lepers to prepare war supplies. Lee Chung-Sang was a leper in the remote island of Sorodo who was incensed by the mistreatment of the lepers and murdered a Japanese captain, Susho Masaki, in 1942 (Sorokdo Nation Hospital 2017). The Japanese imperialist government did not care for the lepers, but rather abused them.

In the Kyeongnam area, the leprosy mission was started by NPCUSA as already mentioned. Dr C.H. Irvin worked on it and, with the help of the Leprosy Mission London, opened the Leprosy Asylum in Gabmandong, Busan, in May 1910 (Mackenzie's Report KMF 1935:19). At that time, they had just two small wards, one for men and one for women (Edith \& Anderson 1970:143). However, NPCUSA carried the financial burden and suggested to the Australian Presbyterian Mission in Korea (APM) that they should join in forming a Leprosy Committee. ${ }^{4}$ In a special meeting in Busanjin in 1911, APM decided to accept the invitation and APM and NPCUSA organised the Leper committee and worked together (Winn's Report; KMF 1912:21). At first, Mackenzie and his friend, Engel, were involved (Mackenzie 1995:141; The Records of the APM 1913:15).

However, Engel had a much greater interest in a teaching ministry in the school than in medical work, whereas Mackenzie's biggest interest was in the medical work. Although he was not a qualified doctor, he had received medical training in his hometown of Glasgow and he also had long experience in medical work in Nogugu, Santo, New Hebrides. In a sense, he was like a doctor without a license. As a result, Mackenzie became the superintendent in the Lepers' House in May 1912.

Furthermore, Mackenzie requested Korean churches to take care of leprosy work. As a result, the Presbyterian General Assembly in Korea organised the Committee of Lepers and collected funds from each Presbytery from 1924 onwards and also appointed a Mission Sunday for Lepers in all churches and supported them from 1932 onwards (Mackenzie's letter; KMF 1935:19). Also, the government was encouraged to create policies concerning leprosy and its sufferers. From 1910, Mackenzie spoke several times to others who were considering this issue and he suggested guidelines to the government. The contents of these guidelines could be summarised; thus: (1) lepers would live in one place so that leprosy could be completely eradicated, (2) leprosy should be treated early and this aim should be promoted through schools and public institutions, (3) the most suitable isolated place was determined to be the southern end of South of Korea, (4) each police station should create a list of all registered patients in their area and the police should check that patients received their injections and (5) the government should provide the required finance to treat this problem more effectively because lepers who practiced begging could be a threat to others (Mackenzie's report; KMF 1935:89-92). In this initiative, the missionaries pursued aims which the government had neglected. Finally, the government took responsibility and accepted the recommendations in depth to create the policy. The Japanese government enforced the special legislation in 1931 and raised funds from citizens in order to prepare for a major hospice, encouraging large donations by giving awards to such donors.

\section{A friend of lepers 5}

Mackenzie greatly extended the Lepers' House because the facilities of the asylum were too small to accommodate more lepers. In November 1913, Mr Bailey, who was a director of the Leprosy Mission in London, visited the Lepers' House. At that time, he donated $\$ 1500$ and promised that their mission would continue to support the Lepers' House (Mackenzie 1995:147). And by the support of one mother and her daughter, the Gennesaret ward for men was built and they also organised a half-penny League and collected funds to build the League Home for women (Jeong 2007:356). In 1913, Rev. John Macrae, who was a senior pastor in the Toorak Presbyterian Church in Melbourne, donated an offering to build the Macrae House for male patients (Mackenzie's Report; KFM 1921:83). In addition, in 1919, Australian money from the Memorial Soldiers' Fund from the First World War was sent to Korea and used for the renovation of buildings. Mrs Murray donated 2000 pounds for facilities for outpatients (Mackenzie 1995:158). She additionally donated her whole property in 1920 for building new housing for women lepers and this was known as Murray's House.

Mackenzie concentrated on improving the hospital building because not all patients could be accepted there. To this end, after he had spent a sabbatical holiday in Scotland in 1924, he then returned to Australia where he collected funds. He also received support of 245 pounds from the Mainichi News press in Osaka with which he renovated the old building so that 40 more patients could be accommodated (Mackenzie Autobiography c.1949:61). He built the modern style hospital by support of one English woman and when Rev. R.W. Macaulay, who was a moderator of PCV, visited the Lepers' House, he opened the new hospital. Also, an English friend of Mackenzie supported the work with a donation of 300 pounds and that was used for further expanding the hospital. In this way, the Lepers' House was changed from being an asylum for refuge to a modern hospital.

Many lepers walked for days in uncomfortable positions, or those who could not walk were carried on others' backs,

5.The term, 'A Friend of Lepers' was the witness of people who received help from Mackenzie's family and was recorded in the KBS broadcast of the documentary by Mackenzie's family and was recorded in the KBS broadcast of the documentary by
the Ilsin Hospital produced on their 50th anniversary. Also, this designation is written on Mackenzie's gravestone (Ilsin Christian Hospital 2012:194). 
often taking weeks to travel for help. But on many occasions, they could not be accommodated because of lack of space. Sometimes, 40 people per day had to be rejected. On one occasion when Mackenzie came out to call a sufferer to fill a vacant space, 53 leprosy patients responded and some of them set out to the affected area, attempting to draw his attention (Mackenzie Autobiography c.1949:45-46).

Yet, the Lepers' House exponentially increased its capacity to house patients. When Mackenzie began serving lepers in 1910, he worked with 34 affected people (Mackenzie Autobiography c.1949:74) ; by 1911, there were 43 people; in 1912 , there were 54 people; in 1914, there were 75; in 1915, there were 132 people; in 1916, there were 150 people; in 1917, there were 153 people; in 1919, there were 150 people; in 1921, there were 180 people; in 1923, there were 337 people; in 1924, there were 363 people; in 1925, there were 400 people; in 1926, there were 450 people; in 1928, there were 500 people; in 1929, there were 560 people; in 1930, there were 562 people; in 1931, there were 580 people; in 1935 , there were 600 people and in 1938, when he expelled from Korea, there were 650 people being treated for leprosy under Mackenzie's care (Lee 2007:483, 485, 490). The Lepers' House was started with just two buildings, but it became a town or community of believers, and had schools for children and adults, a hospital, a church, houses for men and women and a farm. The Lepers' House was possible because Mackenzie reached out to sufferers of leprosy with a heart of compassion.

Everybody wanted to enter the Lepers' House, but they accepted only about four or five patients in a month. Many did not return to their hometowns while they waited for their opportunity to be admitted to the Lepers' House, and in 1916, they made a village for themselves. They began creating fields around the place where they settled and started farming and more than 300 people became a close-knit group in the town. Obviously, their settlement was not formed as the typical small rural town in Korea and at times neighbouring town's people were scattered by police as they burned down patients' houses.

According to an article of a newspaper in 1933, settlement villages had 500-600 people living in them:

\footnotetext{
... Korean lepers in Busan organized their group into the Mutual Aid Society and communicated with other groups nationwide and many lepers came to Busan. There were many lepers from Seomyeon, Dongrae, Busan and around 150 people made a town and went to central Busan to beg. The government were concerned by this and considered a command to disperse in the coming summer months as it could not neglect the good health of residents and they were worried about how to remedy the situation. (The Osaka Asahi 1926:8)
}

Essentially, lepers lived in hiding in caves outside the town. Mackenzie kept supplying them with food and clothes. This news spread among them quickly and the sufferers started coming near to the Lepers' House. At first, they had no 6.Mrs Mackenzie remembered 25 years later -36 people. intention of making villages and thought to just have waiting places for admittance to the Lepers' House and so they went to the city area to beg for their food. But as waiting time was increasingly long, they began farming around their house and huts and so developed the settlement villages. Those who were in the lepers' villages collected funds themselves for food and medicine, and made these community villages to help each other. It was not their purpose to make permanent villages, but only to have temporary accommodation to take care of each other until they entered the Lepers' House. Being admitted to the Lepers' House was not easy, however, and so they then began farming in order to feed themselves. Additionally, people who had no place to go also started living in the villages. They were really the abandoned people of the nation, of society and even of their families and were the most pitiful of people in those times. But they were taking care of each other themselves and rose to create community life in their difficult situation. This was an expression of the solidarity spirit of the marginalised people.

Mackenzie did not ignore the people who could not be admitted. He appointed one staff member who treated them, touring their villages twice a week. And he also cured people, by using those sufferers who did not return to their hometowns and who had medical knowledge. They operated a small clinic centre for giving prescriptions. This became the great clinic centre of their villages. Mackenzie and a staff member visited twice a week, to dispense the medicine and give the injections to them. In 1935, Mackenzie distributed 89567 injections and more than 50000 files of Chaulmoogra Oil to patients in the Lepers' House and the villages (Jeong 2007:360).

Elder Seong-Geun Lee who was treated directly by Mackenzie, testified about that work saying:

\footnotetext{
... Pastor Mackenzie treated us from Masan, Changwon, Kimhae, Ulsan, Milyang, Jinju, Keochang ... etc, in the regional hospital in the Kyeongsang province, and patients were injected with Chaulmoogra Oil when he went there once a week by bicycle. Treatment was free, but you did have to believe in Jesus. Many people who were cured worked as nurses and there were male nurse too... Yes, I still think I have some names - Yeong Bong Kim, SooYeong Kim, Won Sul Hwang ... etc. They became nurses ... (Kim 2016:n.p.)
}

From 1915, there was a developed method of treatment which involved ingesting Chaulmoogra Oil. In addition, with the help of a Korean doctor trained by Dr Willson, the next year, more specialised treatment for leprosy could be carried out and the mortality rate could be significantly reduced from 25\% in 1914 (Mackenzie, Autobiography c.1949:39) to 2.5\% in 1921 (Mackenzie's report; KMF 1931:91). Mackenzie tried to parallel the therapy of physical with spiritual treatment. This reduced the mortality rate to $2 \%$ and 91 people were discharged from hospitals and more than 900 people were treated in 1931 (Mackenzie 1995:180). It was at this time, in 1931, that Mackenzie officially became a doctor by passing the required examination (Mackenzie 1995:180). Mackenzie sent a nurse twice a week to the Lepers' House and five leprosy villages to treat the leprosy patients. 


\section{His treatment theology}

J.N. Mackenzie had confidence that leprosy could be fully cured through a harmonised mix of 'Faith, Oil and Labour' (Mackenzie 1995:47). In this context, faith was the spiritual awakening and growth of the patient, oil was the use of medicines and labour was proper work with exercise for patients. He tried to ensure that patients had proper labour for several reasons. Firstly, labour was given by God to people as a mission and so it is sacred. Secondly, labourers would know the blessing of rest. For those who shed sweat by working hard, it is important to keep the Sabbath day and the Sabbath is to focus on faith rather than simply on not doing work during the day. Thirdly, by labouring, the worker was working for himself as well as for his family and neighbours. Mackenzie believed that working would give motivation and confidence to lepers, especially to those who were filled with frustration and anger and a sense of failure. Therefore, he gave work to all those who stayed in the Lepers' House. For this work, lepers were divided into groups according to their disease status. Seriously, ill patients were exempted from work. Others laboured at housework, cooking, patching clothes to wear, and at farming such crops as vegetables, which were grown for the common meal (Mackenzie 1995:47). Those who lived by begging for something to eat had been admitted to the Lepers' House in earlier times, but as Mackenzie developed the place, they were required to work at farming or cooking for themselves and this brought joy and confidence to them. Those who understood building technology were to build the buildings inside and the non-skilled workers were to do labouring works such as earth moving, making roads and removing weeds. They always understood that their working was for their healthy recovery and for the good of the leprosy family in the house. In addition, Mackenzie distributed their wages which were four or five pence a day and eight pence a month to all workers. With that, they were able to purchase what they needed (The Messenger 1932:742).

Some among the lepers in the Lepers' House had other useful knowledge and skills as they were teachers, nurses, civil servants, office workers and so on. These educated patients were treated as advanced workers and as volunteers in areas such as being guides, teachers, nursing assistants, administrative personnel or farm instructors. People who could not read learned from the Hanguel (Korean) class every morning. They were instructed by an evangelist and by former teachers. People who could read were to attend a Bible study class in the morning and in the afternoon every day. There they were also instructed by an evangelist and teachers. Most of the lepers could not read when they arrived, but after about 6 months' tuition, almost everyone could read. Their commitment to be free from the disease made them determined to do everything they could to help themselves.

Mackenzie fostered faith in three ways. Firstly, all those who entered the Lepers' House were given the Bible and hymns. Secondly, all people learned Christian knowledge from the
Bible in the morning and afternoon classes. Thirdly, all people had worship services every evening to encourage their faith. Previously, many patients had blamed their family, society or the state for their difficulties, but it shook their hearts when they watched Mackenzie's truly loving services. In their heart, the resentment, which was hardened like a stone, melted and they had doubts about their hard stance.

Mackenzie was not a fellow countryman. He was a westerner. They wondered why he would love them so much, especially those who were abandoned by their own society and even their own family. They wondered what prompted him. Mackenzie said that it was God's love and the grace of salvation through our Lord Jesus who died and was crucified. They wondered more about it and so they were diligent in studying the Bible in which this actual story was written. They were always holding their Bibles to their chest, even walking around with them held that way.

There were two Bible study classes daily - in the morning and in the afternoon and there were combined worship services every evening. Those who did the preaching also led the worship. One-hundred years ago, it was not a simple issue for women to move out of their traditional roles, especially in the Kyeongsang province that had the most conservative Confucian culture in Korea with its belief that men were superior to women. The Korean church in Korea did not have consensus for the issue of female pastor ordination until today. Nevertheless, Australian women missionaries were delegated under leadership of a man where there was one, but in the absence of a pastor, they preached and led worship. According to Mary Kelly's diary, written on 21 April 1906 before her marriage to Mackenzie:

... Miss Agnes Brown led the Worship on Sunday twice. But the
women were not surprised as the lady missionary directly led
worship for those who came from the surrounding villages for
worship together ... (Busanjin Compilation Committee 1991:198)

They were in cultural shock, but regardless, were faithful as the essential part was receiving the gospel being preached to them. Therefore, in the Lepers' House when Mackenzie was absent, the women missionaries and teachers who were appointed among them led the worship every evening (Mackenzie 1995:148).

By this process, the Lepers' Church in the Lepers' House first baptised seven men and then three women in 1912 who then took Holy Communion (Mackenzie 1995:147). When they received the sacrament, they were deeply affected and suffered bodily discomfort. We read, 'When they were given the wine, they could drink it only when a helper helped the cup to reach their lips' (Kelly's letter, 03 November 1912; Messenger 1913:99). Then, in 1917, 66 members participated in the Holy Table (Mackenzie 1995:148), and in 1921, they had 111 members and 40 study members in the Lepers' Church. Then, this church established the new building and it was dedicated in 1926 and numbers increased to 234 members in 1931. When Mackenzie retired in 1938, there were more than 400 members (Mackenzie Autobiography c.1949:66). 
In addition, the neighbouring villagers founded churches by themselves. They had regular meetings for Bible study and worship similar to the Lepers' Church. So, the Lepers' Church was as a mother church to them. Then, at some point, Mackenzie visited these churches and also sent teachers to them to train them. Mackenzie trained them in Christian knowledge. These villagers also constructed church buildings for themselves and had dedication ceremonies. Then, they received pastors and grew into healthy churches (Mackenzie Autobiography c.1949:51). In this way, they were organised in their new community around a centre of faith and church life.

\section{Salvation evidence of lepers}

The lepers had changed incredibly in faith. Originally, they were captive people with resentment, frustration and lost confidence because they were abandoned by society, nation and even their family because of leprosy. However, in the Lepers' House, they were cured in body and spirit as well. It was a regrettable mindset that caused some people to throw rocks at them and their families to desert them because they were ashamed of them being lepers. But they received Christian knowledge through Bible study and preaching. They had learned that for the salvation of disobedient sinners, God sent his only son, Jesus, to this sinful world, and for an ugly sinner, he had died by crucifixion and through this made forgiveness for our trespasses and sins available. And also, they knew through the witness of Mackenzie's life, how a Christian lives in this truth as he lived as their friend and teacher. Therefore, by the love of Jesus, the lepers were slowly able to forgive those who had hurt them.

They were convinced that true forgiveness is not only to have resentment removed from the heart, but also to evangelise other people, telling them the gospel. They believed that as people who had received the love of Jesus, they must share that love with others. They became evangelists. In 1919, some of the people among them requested to be sent outside for 4-6 months. The reason was that they wanted to go outside and preach to the people they had met during their time of begging for food. They thought that they received great love in the Leper's House which had healed their minds and bodies and they must share this grace with others (Mackenzie, Leper Work in Fusan [21 May 1932]; KMF 1933:82-84). Mackenzie agreed to their going and gave each one a certificate of promise to re-enter the house. As a result, some of the lepers who came in the Lepers' House had Christian knowledge already because these leper evangelists had met them. They continued in commitment to the Lord, which was evidenced in 1920, in the offering time in Sunday worship when they made sacrificial offerings from money which was all that they had received for some months to buy their basic necessities. However, they offered a large part as thanks offerings and the tithes. This church was the first to collect offerings, and they sent 27 yen to the foreign missions. Furthermore, they sent an evangelist to a lepers' village and he was supported as he went on behalf of those who were not able to go. Additionally, in 1925, they decided another evangelist was to be sent, not to a lepers' village, but to a normal town, and they sent Chang S. Moon to the Milyang region (The record of the Kyeongnam Presbytery July 1925). Also, from 1926 to 1933, they supported the wages of evangelist Yang-Won Son ${ }^{7}$ who was the most respected person in the Korean Church. He established three churches in that area (Edith \& Anderson 1970:84) and then he graduated from the Union Theological Seminary in Pyeongyang and became a pastor at the Aeyangwon Church in the Asylum of Lepers in Suncheon. ${ }^{8}$

This family of lepers was known to deeply respect and love Mackenzie. Their love and respect was proved when he had a third sabbatical holiday in Melbourne at a time when he was past retirement age. The family of lepers was concerned that he may not be allowed to come back to them and so they recommended to the Presbytery that he should be able to come back again and the clerk, Moon T. Kim, sent the official letter to PCV. In the letter, they acknowledged that at 66 years of age, he was at retirement age, but they requested that he came back to them as he was so respected by the Koreans. According to this letter:

... this Kyeongnam Presbytery ... have heard the news that his
retirement time is near and we decided to entreat you that he be
returned quickly to South Korea .... after Mackenzie left for the
sabbatical holiday, we were like a child who had lost his parents;
as sheep without a shepherd ... we are truly waiting for Mr. and
Mrs. Mackenzie to come back quickly to us ... (PCV Proceedings
1932:101)

According to their requests, Mackenzie was not retired and he returned to Busan, South Korea, in September 1932.

Then, this grateful family of lepers erected a granite monument in the Lepers' House on Mackenzie's 20th mission anniversary and also erected the Memorial steel gate at the entrance for his mission's 25th anniversary. Another evidence of their great love for Mackenzie was when they sent out an evangelist to another place and called him Mackenzie's Memorial Evangelist, though he called himself 'The Leper Self-denial Evangelist' (Mackenzie 1995:81, 194, 196).

Dr Robert Cochrance, who was Secretary for Medical work of the Mission to Lepers, visited the church and left these words, '... In fact, the evangelistic work among the lepers in Korea is the finest I have ever witnessed' (Mackenzie, Autobiography c.1948:52).

His opinion would have been most accurate. Also, another officer said:

7.Yang Won Son (1902-1950) is the most respected person in the Korean Church. $\mathrm{He}$ was born in Haman, the South Kyeongsang province, and worked 8 years as an evangelist in the Lepers' House and learned from J.N. Mackenzie about loving lepers. Then, he graduated from the Union Theological Seminary in Pyeongyang and was appointed Pastor at the Aeyangwon Lepers' Church in Sooncheon. In 1948, in communist uprising in that town, his two sons, Dong-In and Dong-Sin, were killed. Police arrested the killer, Kang Je-Sung. But Yang Won Son requested the judge to give Police arrested the killer, Kang Je-Sung. But Yang Won Son requested the judge to give him the murderer of his sons as his stepson to show him how to live and finally this was granted. Two years later, the evangelist was martyred by a communist (The Kyeongnam Presbytery 2006:106-110). J.N. Mackenzie expressed, 'He was my best friend and
was the most passionate of evangelists' (Mackenzie, Autobiography c.1949:64).

8.This asylum was moved from Gwangjoo of Dr R.W. Willson to Suncheon in 1928 and changed name to the Aeyangwon in 1936. 
You have to put police at the gates to keep lepers out and we have to put police at our gates to keep lepers from running away. I know what it is, you have faith and we don't. (Mackenzie, Autobiography c.1948:59)

In the end, Mackenzie was with the lepers who were marginalised from their families and society and he administered parallel treatments for their diseases of spirit and body so that they were not only cured in body, but also in spirit. They became evangelists, sharing the gospel with others and sending evangelists on their behalf. It is reminiscent of the work of Jesus in Galilee. He came as the light to the hopeless in The Galilee; Mackenzie was like a light to lepers in Busan, South Korea, and then the lepers sent evangelists to the world. An aspect of Jesus in Galilee was reproduced through lepers in Busan.

\section{Conclusion}

In Korea a century ago, leprosy, which came early in human history, was misunderstood as a plague, an inherited disease and a curse of God and lepers were utterly abandoned by their families and society. However, Australian missionary Mackenzie applied his unique therapeutic theology to them with the amazing results of greatly reducing the mortality rate and of bringing many to faith in Christ. Also, the lepers who became Christians forgave those who had previously abandoned them and sent them evangelists who went representing all the Christian lepers.

This method of Mackenzie's mission was a way of reaching out to the upper classes by preaching to the marginalised people first. It was a holistic mission of service that broke the boundaries between church and society.

Mackenzie, who became a friend to those who were the most alienated at the time, is a representation of Jesus. He is reminiscent of Christ who became a friend of sinners in Galilee (Mt 11:19).

\section{Acknowledgements Competing interests}

The author declares that he has no financial or personal relationships that may have inappropriately influenced him in writing this article.

\section{References}

Busanjin Compilation Committee (ed.), 1991, Busanjingyohoe 100nyeonsa [100 Years history of Busanjin Church], Busanjin Church, Busan.

'Busan Jiyeok Sosik' [Busan Area News], The Osaka Asahi Newspapers, Choseon Edition, 26 June, 1926, p. 8.

Busan Presbytery (eds.), 2005, Busannohoesa [The history of Busan Presbytery], Dongbang, Busan.

Chae, G.T., 2006, Hankook Hansenbyeong Geunjeoleulwihan Yeoksajeog Baegyeong [Historical background for the elimination of the Korean Leprosy], Institute of Hansen's Disease, viewed 08 June 2016, from https://hansen.re.kr:49732/home/ sub/doc_22.php

Edith, K.A. \& Anderson, G., 1970, The Australian mission to Korea, 1889-1941, Australian Presbyterian Board of Missions, Sydney.

Ilsin Christian Hospital (ed.), 2012, Mekenzigauiddadul [Mackenzie's daughters: Memories of Helen Pearl Mackenzie, Catherine Margaret Mackenzie missionaries], Ilsin Christian Hospital Alumni, Busan.

Jeong, B.J., 2007, HojujangrohoeSeongyusadeuluiSinhaksasanggwahankookseongyo [Australian Presbyterian missionaries' theological thought and Korean missions 1889-1942], HankukKidokkyoYeoksaYeonguso [The Institute of the History of Christian in Korea], Seoul.

Kelly, J.T., 'Letter', 03 November, 1912, in The Messenger, 14 February, 1913, Hope, Lyle, Hooton \& Sommerville, Maroubra, NSW.

Kim, W.P., 2016, 'Mekenjiseongyosa' [Missionary James. N. Mackenzie], The Christian Journal, viewed 31 May 2016, from http://www.kcjlogos.org/news/articleView. html?idxno=5402

Lee, M.Y., 2007, HankookGidonkyuwaMinjokundong [The Korean Christian and National Movement], HankukKidokkyoYeoksaYeonguso [The Institute of the History of Christian in Korea], Seoul.

Mackenzie, H.P. 1995, Mackenzie, Man of Mission: A Biography of James Noble Mackenzie, Hyland House, Melbourne.

Mackenzie, J.N., 'Letter', 15 December, 1908, in Messenger, 29 January, 1909.

Mackenzie, J. N., 'Leper work in Fusan', in Korea Mission Field, April 1921, Federal Council of Evangelical Missions in Korea, Seoul.

Mackenzie, J.N., 'The Leper Situation in Korea', in Korea Mission Field, May 1931 Federal Council of Evangelical Missions in Korea, Seoul.

Mackenzie, J.N., 'Leper work in Fusan', 21 May, 1932, in KMF, 1933, Federal Council of Evangelical Missions in Korea, Seoul.

Mackenzie, J.N., 'Leper report', July 1933. 'Fusan Leper Colony', Korea Mission Field, January 1935, Federal Council of Evangelical Missions in Korea, Seoul.

Mackenzie, J.N., c.1948, Rev. James Noble Mackenzie, An Autobiography, E. MacKerchar (ed.), The Mission to Lepers, London.

PCV [The Presbyterian Church of Victoria, Australia], 1932, Proceedings, The Church, Melbourne.

Sorokdo Nation Hospital, 2017, 'WonsaengdeuluiNodonggwasunan' [Labor and suffering of lepers], viewed 22 March 2017, from http://www.sorokdo.go.kr/ sorokdo/board/sorokdoHtmlView.jsp?menu_cd=03030110

Suzuki Kawashima, 2012, 'Current status of leprosy: Epidemiology, basic science and clinical perspectives', The Journal of Dermatology 39(2), 121-129.

The Kyeongnam Presbytery (eds.), 2006, The history of Kyengnam Presbytery, Kumran, Seoul.

The Messenger, Korea Mission Field, 20 May, 1932, Hope, Lyle, Hooton \& Sommerville, Maroubra, NSW.

'The Record of the Kyeongnam Presbytery' [The South Kyeongsang Presbytery], July 1925.

The Records of the APM [Australian Presbyterian Mission], Korea Mission Field, 1913, Federal Council of Evangelical Missions in Korea, Seoul.

The Society of Korean Leprologists, 2016, viewed 02 June 2016, from http://www. leprosy.or.kr/webpage/01guide/guide03.asp

Winn, G.H., 1912, 'Report of the Fusan Leper Asylum 1910', in Korea Mission Field, n.p., January, Federal Council of Evangelical Missions in Korea, Seoul. 